\title{
Assessing the nuclear level impacts upon exposure to Bispyribac- sodium and Carbosulfan in Poecilia reticulata and Aplocheilus parvus
}

\author{
G.K. Achini W. Fernando ${ }^{1}$, Sevvandi Jayakody ${ }^{1 *}$, W.M.H. Kelum Wijenayake ${ }^{1}$, Gawrie N.L. \\ Galappaththy $^{2}$, Mangala Yatawara ${ }^{3}$, R.D. Jeevanie Harishchandra ${ }^{4}$ \\ ${ }^{1}$ Department of Aquaculture and Fisheries, Wayamba University of Sri Lanka, Makandura, \\ Gonawila, Sri Lanka. \\ ${ }^{2}$ World Health Organization,. Global Malaria programme, Geneva, Switzerland. \\ ${ }^{3}$ Department of Zoology and Environment Management, University of Kelaniya, Kelaniya, Sri \\ Lanka. \\ ${ }^{4}$ Anti Malaria Campaign, Colombo 05, Sri Lanka. \\ *Correspondence (sevvandi_jayakody@yahoo.com) \\ (iD https://orcid.org/0000-0001-9600-4986
}

\begin{abstract}
Conventional chemical controlling, due to harmful effects on the environment and animal health, is less appreciated and discouraged today. The impacts to exposed organisms are multiple, but changes at nuclear level can result in long-term impacts to exposed populations. Such chemical exposure can also negatively impact fish that are intentionally introduced to aquatic systems for mosquito vector control. Hence, two types of fish, guppy (Poecilia reticulata) and dwarf panchax (Aplocheilus parvus) used for mosquito control, were tested to the sensitivity to insecticide, Carbosulfan, and weedicide, Bispyribac-sodium in the present study. Lethal average concentration ( $\left.\mathrm{LC}_{50}\right)$ was measured for both chemicals. Gills and liver of moribund and survived fish were stained with Heamotoxyin and Eocin to determine the histological changes. Level of cell necrosis was calculated through terminal deoxynucleotidyl transferase-mediated d'UTP nick end labeling (TUNEL) method. The $96 \mathrm{~h}$ acute $\mathrm{LC}_{50}$ value of Bispyribac-Sodium to A. parvus and $P$. reticulata were $1.280 \mathrm{mg} \mathrm{L}^{-1}$ and $2.370 \mathrm{mg} \mathrm{L}^{-1}$ respectively. The $96 \mathrm{~h}$ acute $\mathrm{LC}_{50}$ value of Carbosulfan to $A$. parvus and $P$. reticulata were $0.315 \mathrm{mg} \mathrm{L}^{-1}$ and $0.028 \mathrm{mg} \mathrm{L}^{-1}$ respectively. Lamellar fusion, filament and lamellar epithelium proliferation, curling of secondary lamellae, hypoplasia and necrosis in gills were observed in treated fish. The percentage of damaged nuclei in the liver of treated A. parvus to Bispyribac-sodium indicated a significantly higher number of damaged nuclei in all treatments except in the lowest concentration $\left(0.025-0.075 \mathrm{mg} \mathrm{L}^{-1}\right)$ compared to control $(\mathrm{P}<0.005)$. P. reticulata which were exposed to Carbosulfan resulted in a significantly higher percentage of damaged nuclei in all treatments $\left(1.10-1.85 \mathrm{mg} \mathrm{L}^{-1}\right) \mathrm{compared}$ to control group $(\mathrm{P}<0.005)$. Results highlighted potential nuclear level impacts due to exposure to Bispyribac-sodium and Carbosulfan. In addition to determining $\mathrm{LC}_{50}$ for chemcials, studies should also focus on surviving fish and their genetic make up.
\end{abstract}

Keywords: Aplocheilus parvus, Bispyribac-sodium, Carbosulfan, $\mathrm{LC}_{50}$, Poecilia reticulata, TUNEL Staining

\section{INTRODUCTION}

Scientists have recently cautioned that more than the number of species that are killed, the individuals that survive after an exposure to chemicals can pose threats to the species' future, as survivors can potentially transfer muted/damaged genetic material to next generations (Malins and Gunselman 1994; Ayas et al. 2007, Simoniello et al. 2009; Ribeiro et al. 2013). Further, genotoxic compounds represent major ecological challenges, which may lead to unusual disorders that could be transmitted to the next generations (Haldsrud and Krokje 2009). The increase of chemical releases into water bodies has created series of deleterious effects for aquatic organisms, besides direct and indirect hazards to human health (Simoniello et al. 2009). Certain pollutants may not cause acute effects but in the long run, they may decrease the life span (Nehls and Segner 2001). Hence, just as the subsequent development of resistance (Humphries 2013) through genetical modifications, attention is also required on damages to cell nuclei of exposed species.

As a result of above problems, exploring alternative, environmentally sounds methods to avoid introduction of chemicals is promoted (Kumar and Hwang 2006; Mattews 2011). One such option 


\section{G.K.A.W. Fernando et al.}

is the use of biological control of vectors. For an example, larvivorous fish like Gambusia affinis (Ghosh et al. 2011), Poecilia reticulata (Kusumawathie et al. 2006) and Gambusia holbrooki (Willems et al. 2005), have been introduced globally, to control mosquito-borne diseases. However, the effective use of any biological control agent depends on the hardiness of the introduced species (Chandra et al. 2008). In tropics, aquatic systems, both lentic and lotic, are increasingly polluted ( $\mathrm{Li}$ et al. 2009). Therefore, in addition to screening for consumption of targeted vector organism, they should also be tested for the tolerance and survival under agricultural and industrial pollutant loadings (Chhonkar et al. 2000).

In Sri Lanka, exotic guppy ( $P$. reticulata) has been widely recommended and released as a biological control agent (Kusumawathie et al. 2008). Further, genus Aplocheilus (Family: Aplocheilidae) also has been successfully tested and used (Wickramasinghe and Costa 1986; Chandra et al. 2008). Compared to $P$. reticulata which is exotic to Asia, Family Aplocheilidae is native. In Sri Lanka, Aplocheilus parvus is a commonly found nativve species and has been documented as a native candidate for biological control of mosquito larvae. Both species are, however, exposed to pesticide and weedicide loadings during the farming season due to haphazard use of chemicals and release of effluent water. Therefore, a study was conducted to test the sensitivity of native $A$. parvus and exotic $P$. reticulata to a widely used insecticide, Marshal $20 \odot$ (Carbosulfan) and a weedicide, Nominee $($ ) (Bispyribac-sodium) with the aim of calculating $50 \%$ Lethal Average Concentration $\left(\mathrm{LC}_{50}\right)$, histological changes in gills and the level of cell necrosis in liver.

\section{MATERIALS AND METHODS}

Determining the sensitivity of $A$. parvus and $P$. reticulata to some selected chemicals used in paddy culture

About 300 A. parvus and $P$. reticulata (150 males and 150 females) were captured by hand nets from a perennial reservoir and a manmade canal during May 2014. Fish were acclimated to laboratory conditions in glass aquaria filled with aged tap water for 2 weeks. Stock solutions of Carbosulfan and Bispyribac-sodium were made by diluting commercial formulations of the chemicals with distilled water to obtain the required concentrations. In the case of Bispyribac-sodium, the same amount of surfactant (a mixture of Nonyl phenol polyethylene glycol ether and Poly ethylene glycol) was used as recommended by the manufacture in order to dissolve the chemical.

\section{Preparation of aquaria}

Aquaria were prepared applying the standard procedures and range finding tests (EPA 1996) were carried out for each chemical for both the species using two replicates with five fish each.

\section{Definitive test-96 hours acute toxicity test}

In this study, 96 hours static system was followed throughout the experiment. Five concentrations of test solutions were used in the definitive test with each concentration replicated in thrice with control aquaria with 5 males and 5 females each. Feeding was terminated 48 hours prior to the initiation of the experiment. The aeration was stopped only during dosing period. Mortality, temperature, $\mathrm{DO}$ and $\mathrm{pH}$ of each aquarium was recorded hourly. Percentage mortalities under each concentration at 96 hours were $\log$ transformed and were analyzed using probit analysis to determine the $\mathrm{LC}_{50}$.

A dilution series of $0.025,0.0375,0.05,0.065$, $0.075 \mathrm{mg} \mathrm{L}^{-1}$ was used for Bispyribac-sodium for $A$. parvus, while $2.00,2.25,2.50,2.75,3.00 \mathrm{mg} \mathrm{L}^{-1}$ was used for $P$. reticulata for the same chemical. In the case of Carbosulfan 0.25, 0.30, $0.35 \mathrm{mg} \mathrm{L}^{-1}$ and 1.10, $1.25,1.40,1.75,1.85 \mathrm{mg} \mathrm{L}^{-1}$ dilution series was used for $A$. parvus and $P$. reticulata respectively.

Live or moribund fish were fixed in $10 \%$ buffered formalin separately as the death occurred in different treatments. The staining adopted in the current study is Hematoxylin and Eosin method (Meyers 2000). In addition, TUNEL staining was used to reveal cellular level damages (Gavrieli et al. 1992; Zhu et al. 2002; Qu et al. 2006). Hundred cells from liver were selected randomly from each stained slide and number of cells showing cell necrosis was calculated under Stereo Zoom Microscope (x100). Between 1500-2500 cells from 5 replicate slides were observed for each treatment. Percentage of cells indicating some form of cell damage was calculated for each agro chemical for each 


\section{G.K.A.W. Fernando et al.}

concentration. The percentages were compared against the control and also between different treatments using Tukey's mean separation in ANOVA. Minitab (version 15) software was used in analysing data.

\section{RESULTS}

\section{LC $_{50}$ values for Bispyribac-sodium}

The calculated $96 \mathrm{~h}$ acute $\mathrm{LC}_{50}$ value and $95 \%$ confidence limits of Bispyribac-sodium to $A$. parvus (weight: $\bar{x}=0.14 \pm 0.004 \mathrm{~g}$; total length: $\bar{x}=25.5 \pm 2.9$ $\mathrm{mm}$ ) were $1.28 \mathrm{mg} \mathrm{L}^{-1}$ and $1.070-1.874 \mathrm{mg} \mathrm{L}^{-1}$ respectively. The calculated $96 \mathrm{~h}$ acute $\mathrm{LC}_{50}$ value and $95 \%$ confidence limits for $P$. reticulata (weight: $\bar{x}=0.210 \pm 0.126 \mathrm{~g}$; total length: $\bar{x}=25.1 \pm 4.3 \mathrm{~mm})$ were $2.370 \mathrm{mg} \mathrm{L}^{-1}$ and $2.028-3.019 \mathrm{mg} \mathrm{L}^{-1}$ respectively. In both the occasions, control mortality was zero.

\section{$\mathrm{LC}_{50}$ values for Carbosulfan}

The calculated $96 \mathrm{~h}$ acute $\mathrm{LC}_{50}$ value and $95 \%$ confidence limits of Carbosulfan to $A$. parvus (weight: $\bar{x}=0.14 \pm 0.004 \mathrm{~g}$; total length: $\bar{x}=25.6 \pm 2.9$ $\mathrm{mm}$ ) were $0.315 \mathrm{mg} \mathrm{L}^{-1}$ and $0.027-0.799 \mathrm{mg} \mathrm{L}^{-1}$ respectively. For $P$. reticulata (weight: $\bar{x}=$ $0.210 \pm 0.126 \mathrm{~g}$; total length: $\bar{x}=25.1 \pm 4.34 \mathrm{~mm}$ ) LC $\mathrm{L}_{50}$ value were $0.028 \mathrm{mg} \mathrm{L}^{-1}$ and $0.0799-0.272 . \mathrm{mg} \mathrm{L}^{-1}$ respectively. In both the occasions control mortality was zero.

\section{Histological alterations in the exposed tissue due to Bispyribac-sodium and Carbosulfan}

\section{Histological changes in gill tissues}

The microscopic examination of the gills in $A$. parvus and $P$. reticulata for weedicide and insecticide revealed several histological changes. These included lamellar fusion, filament and lamellar epithelium proliferations, curling of secondary lamellae, hypoplasia and necrosis (Figs. 1a-g).

\section{TUNEL staining}

Results indicated a significantly higher number of damaged nuclei in the liver in all treatments except in the lowest concentration $\left(1.1 \mathrm{mg} \mathrm{L}^{-1}\right)$ compared to control for $A$. parvus treated with Bispyribac sodium. (ANOVA, $d f_{5,54}, \mathrm{P}<0.005$ ) (Fig. 2 and Fig. 4).

Similar results were obtained for $P$. reticulata which were exposed to Carbosulfan, with a significantly higher percentage of damaged nuclei in cells in all treatments compared to control group (ANOVA, $d f_{5,54}, \mathrm{P}<0.005$ ) (Fig. 3).

\section{DISCUSSION}

The current study highlighted the damages that have occurred to nuclei in the liver of the treated fish compared with the control. The terminal deoxynucleotidyl transferase mediated d'UTP nick end labeling (TUNEL) method, based on direct, specific, labeling of DNA breaks is considered highly specific for the detection or early apoptosis stages, when apoptotic cells are not yet morphologically recognizable (Gavrieli et al. 1992; Negoescu et al. 1998). Among all the organisms, fish are particularly vulnerable and heavily exposed to pollution because they cannot escape from the detrimental effects of pollutants (Yarsan and Yipel 2013). Similar liver apoptosis was also observed in Atlantic bluefin tuna (Thunnus thynnus) found in the northern Adriatic Sea exposed to pollutants (Corriero et al. 2013). At present, organisms are exposed to a complex mixture of contaminants as toxic metals, organoclorides compounds, polycyclic aromatic hydrocarbons (PAHs) and sewage. Thus, depending on the dynamics of hydrographical and geomorphological conditions, the bioavailability can increase, providing more opportunities to contact with those pollutants (Haldsrud and Krokje 2009; Kousar and Javed 2015).

Histological findings from this study reiterated the susceptibility of gills and liver to tested chemicals, The large surface area of the secondary epithelium makes the gill a well-known target organ in fish and it is the first organ to react to environment pollutants (Bernet et al. 1999; Dalzell and Macfarlane 1999). The gill alterations including lamellar fusion, filament and lamellar epithelium proliferations, curling of secondary lamellae, hypoplasia and gill necrosis for A. parvus and $P$. reticulata for both agro-chemicals supported a similar finding by Heo and Shin (2009) and Çaliskan et al. (2003) for A. parvus. 
The calculated $96 \mathrm{~h}$ acute $\mathrm{LC}_{50}$ value of Bispyribac-sodium for $A$. parvus was lower than for $P$. reticulata which indicated the more sensitive nature of $A$. parvus compared to $P$. reticulata for the weedicide. According to the material data sheet of Bispyribac-sodium, the $\mathrm{LC}_{50}$ value of rainbow trout

(a)

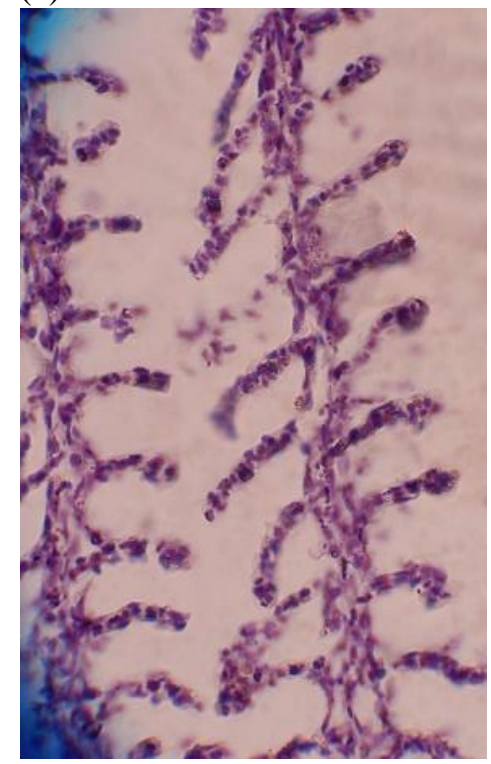

(d) (b)

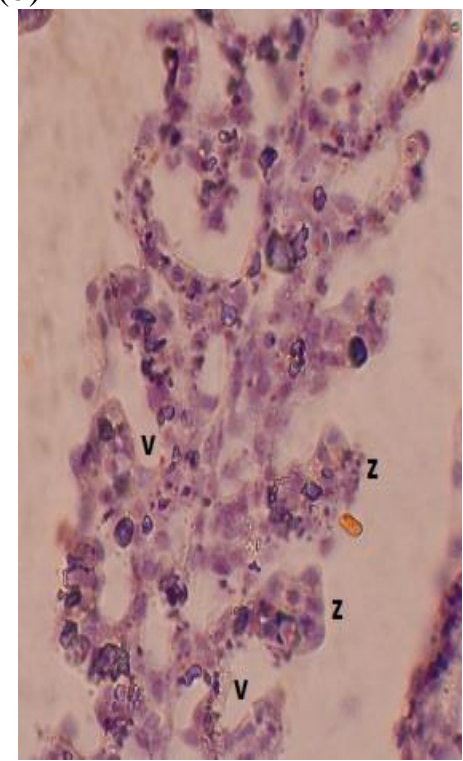

(f) (c)

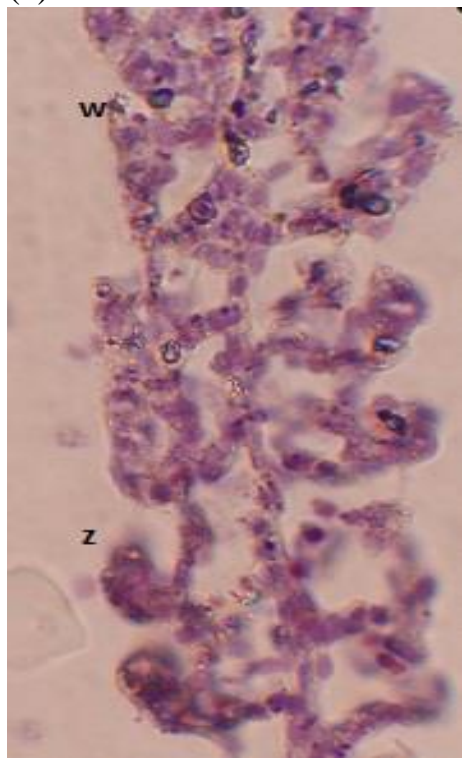

(g)

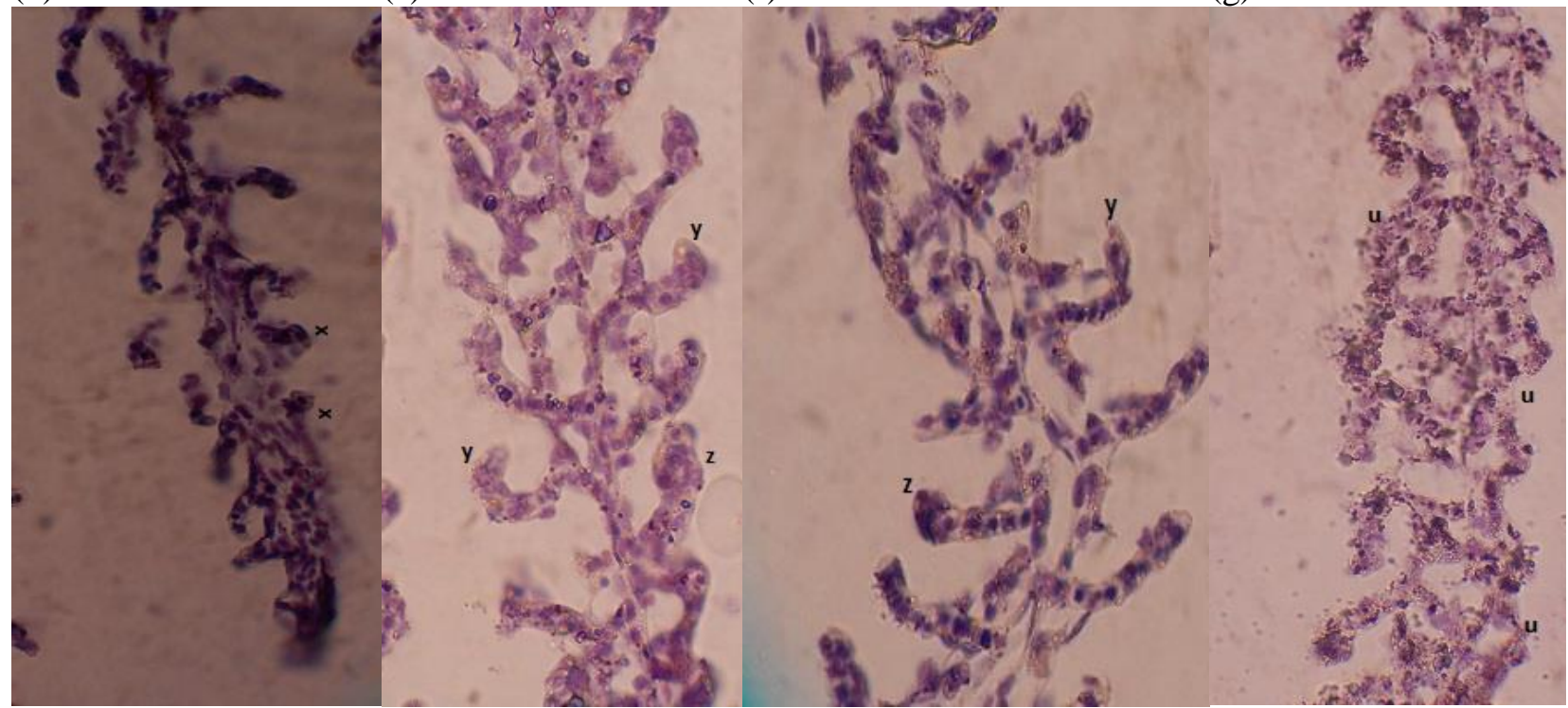

Figure 1 Gills of $P$. reticulata stained with Heamotoxyin and Eocin. a: control treatment; b-g exposed to Bispyribac-sodium and Carbosulfan. Figures show lamellar fusion (w); filament and lamellar epithelium proliferations (z); curling of secondary lamellae (y); hypoplasia (v) and necrosis (u) (10x10 magnification). 


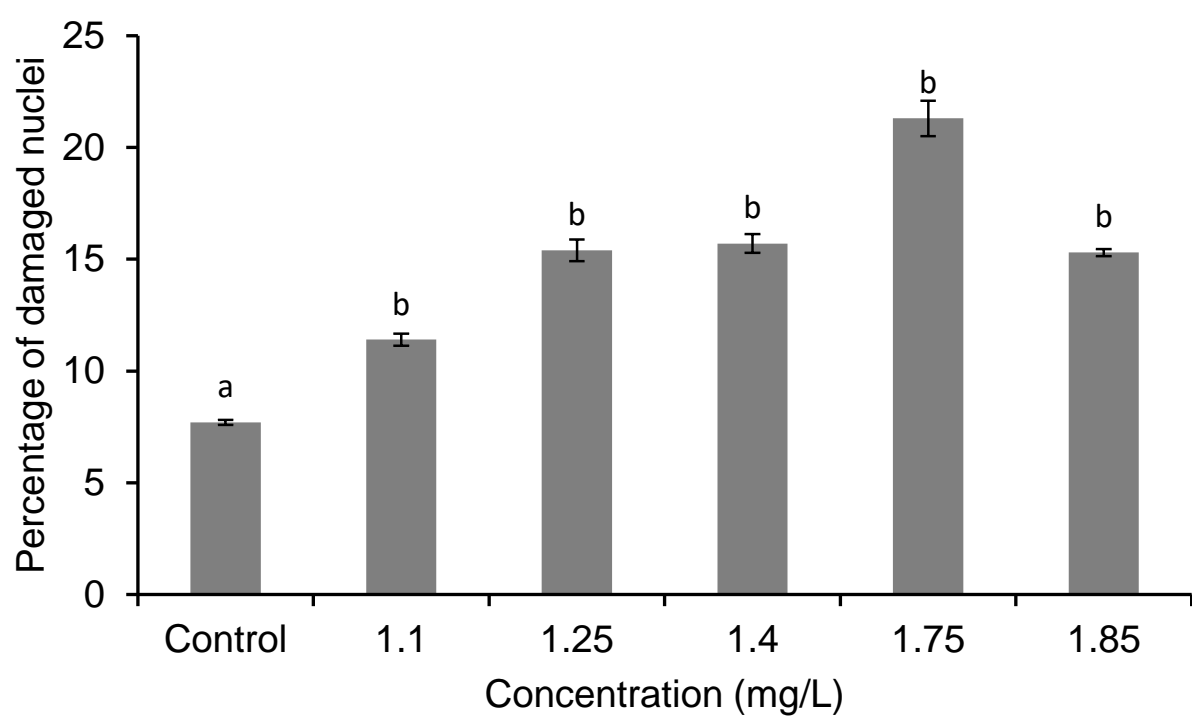

Figure 2 The percentage of damaged nuclei of the liver tissues of A. parvus exposed to Bispyribac-sodium. Means with different letters are significantly different (Tukey's Test, $\mathrm{P}<0.005$ ).

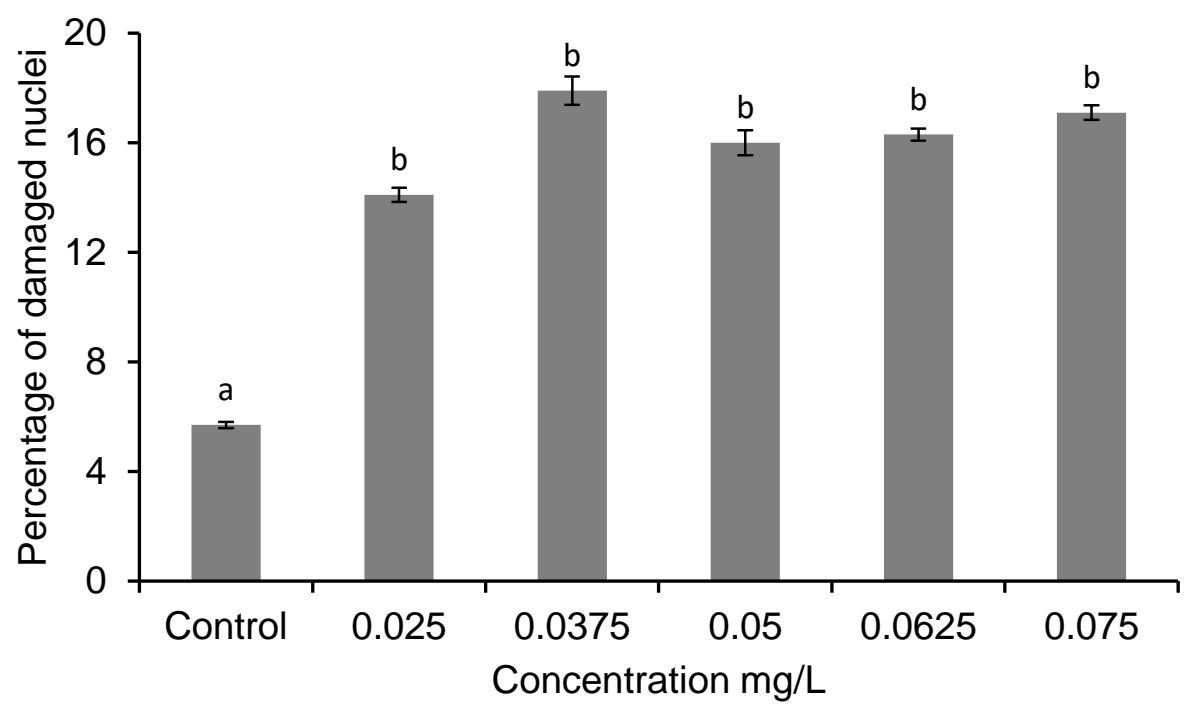

Figure 3 The percentage of damaged nuclei of the liver tissues of $P$. reticulata exposed to Carbosulfan. Means with different letters are significantly different (Tukey's Test, $\mathrm{P}<0.005$ ). 


\section{G.K.A.W. Fernando et al.}

$(\mathrm{x})$

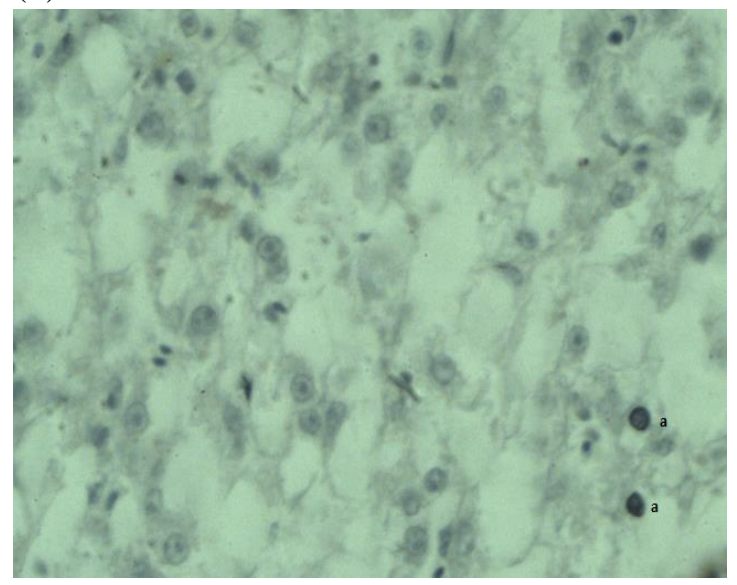

(z)

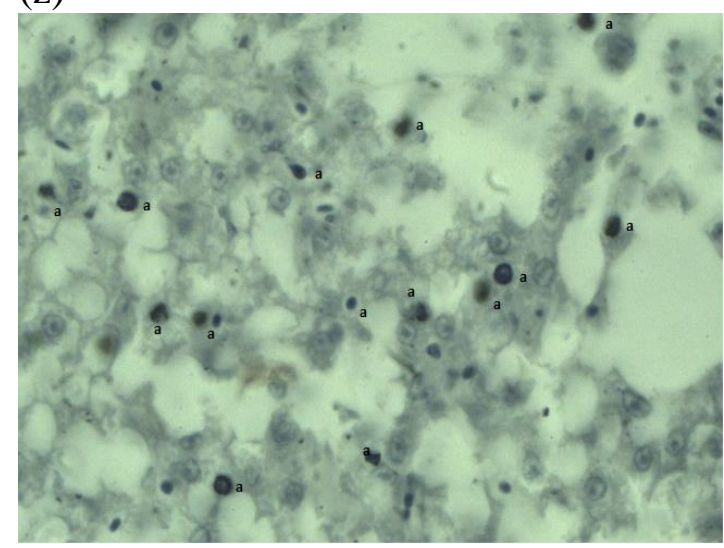

(y)

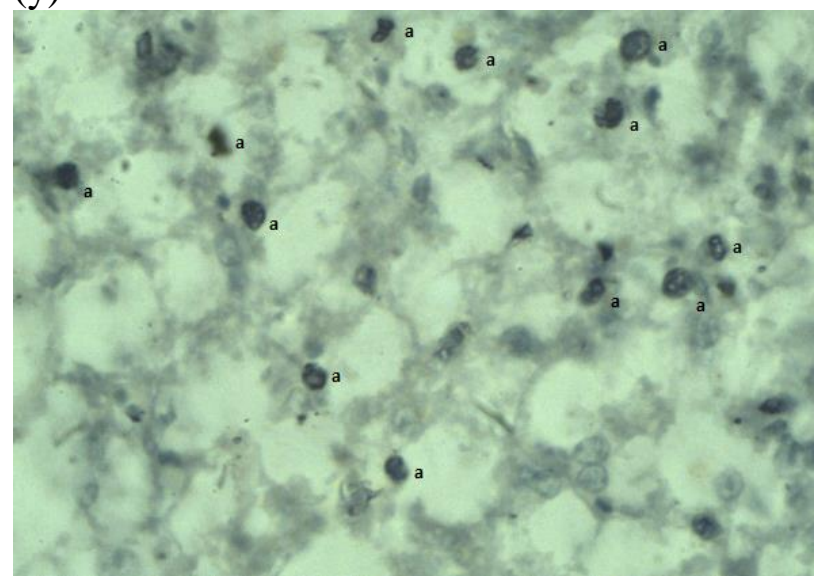

Figure 4 Damaged nuclei of the liver tissues of A. parvus exposed to Bispyribac-sodium. x: control; y and $\mathrm{z}$ : treatments (1.25 and $1.75 \mathrm{mg} \mathrm{L}^{-1}$ respectively). Letter "a" marked in plates depicts the damaged nuclei.

obtained from the current experiment which emphasize the need to test the tolerance for a wider range of species than relying on studies done elsewhere for non-related species.

Bispyribac-sodium is applied with a surfactant and the current results are for the combined toxicity of both. The combined effects and toxicity by itself has also been tested by others. For instance, Wan et al. (1989) found that in a commercial formulation of glyphosate, the added surfactant was more toxic than the active constituent, glyphosate. Further, laboratory studies have also shown that glyphosate alone has a low toxicity, while the surfactant can be highly toxic to a variety of taxa including amphibians (Mann and Bidwell 1999; Lajmanovich et al. 2003).

The $96 \mathrm{~h} \mathrm{LC}_{50}$ for $P$. reticulata for Carbasulfan $\left(0.028 \mathrm{mg} \mathrm{L}^{-1}\right)$ was lower than the values reported by Boran et al. (2007) for the same species $(0.122 \mathrm{mg}$
$\left.\mathrm{L}^{-1}\right)$. However, in the current study $96 \mathrm{~h} \mathrm{LC}_{50}$ for $A$. parvus was much higher $\left(0.315 \mathrm{mg} \mathrm{L}^{-1}\right)$ than previously reported. For example, the $96 \mathrm{~h} \mathrm{LC}_{50}$ calculated for the Carbosulfan for Channa punctatus was $0.268 \mathrm{mg} \mathrm{L}^{-1}$ (Nwani et al. 2010), $0.231 \mathrm{mg} \mathrm{L}^{-1}$ for Oncorhrincus mykiss (Boran et al. 2007) and 1.2 $\mathrm{mg} \mathrm{L}^{-1}$ for Labeo rohita (Nagaraju and Rathnamma 2014), $0.042 \mathrm{mg} \mathrm{L}^{-1}$ for rainbow trout (Yi et al. 2006) and $0.015 \mathrm{mg} \mathrm{L}^{-1}$ for bluegill sunfish (Boran et al. 2007). Therefore, this study also affirms the fact $\mathrm{LC}_{50}$ of this pesticides varies from species to species and for the same species under the influence of number of factors including size, time of exposure (Nagaraju et al. 2011), hardiness of the test species and water quality parameters (Nwani et al. 2010). Overall, both the species selected in the current study exhibited their sensitivity towards tested toxicants and the results indicated the likely 


\section{G.K.A.W. Fernando et al.}

interferences of agro chemicals with future biological control programs in Sri Lanka.

\section{Acknowledgement}

This study was carried out as part of a research project funded by Global Fund to Fight AIDs, Tuberculosis and Malaria (GFATM).

\section{REFERENCES}

Ayas, Z., G. Ekmekci, M. Ozmen and S.V. Yerli 2007. Histopathological changes in the livers and kidneys of fish in Sariyar Reservoir, Turkey. Environmental Toxicology and Pharmacology 23(2): 242-249. doi: 10.1016/j.etap.2006.11.003.

Bernet, D., H. Schmidt, W. Meier, P. BurkhardtHolm and T. Wahli 1999. Histopathology in fish: proposal for a protocol to assess aquatic pollution. Journal of Fish Diseases 22(1): 25-34. doi: 10.1046/j.1365-2761.1999.00134.x.

Boran, M., I. Altinok, E. Capkin, H. Karacam and V. Biçer 2007. Acute toxicity of Carbaryl, Methiocarb, and Carbosulfan to the Rainbow Trout (Oncorhynchus mykiss) and Guppy (Poecilia reticulata). Turkish Journal of Veterinary and Animal Sciences 31(1): 3945.

Çaliskan, M., B. Erkmen and S.V. Yerli 2003. The effects of zeta cypermethrin on the gills of common guppy Lebistes reticulatus. Environmental Toxicology and Pharmacology 14(3): 117-120. http://doi.org/10.1016/S13826689(03)00046-2.

Chandra, G., I. Bhattacharjee, S.N. Chatterjee and A. Ghosh 2008. Mosquito control by larvivorous fish. Indian Journal of Medical Research 127(1): 13-27.

Chhonkar, P.K., S.P. Datta, H.C. Joshi and H. Pathak 2000. Impact of industrial effluents on soil health and agriculture - Indian experience: Part I - Distillery and paper mill effluents. Journal of Scientific and Industrial Research 59(5): 350361.

Corriero, A., R. Zupa, C. Pousis, N. Santamaria, G. Bello, E. Jirillo and L. Passantino 2013. Increased liver apoptosis and tumor necrosis factor expression in Atlantic bluefin tuna (Thunnus thynnus) reared in the northern Adriatic Sea. Marine Pollution Bulletin 71(1): 23-28. http://doi.org/doi:10.1016/j.marpolbul.2013.03.0
41.

Dalzell, D.J.B. and N.A.A. Macfarlane 1999. The toxicity of iron to brown trout and effects on the gills: a comparison of two grades of iron sulphate. Journal of Fish Biology 55(2): 301315. http://doi.org/10.1111/j.10958649.1999.tb00680.x

EPA 1996. Ecological Effects Test Guidelines (OPPTS 850.1075): Fish Acute Toxicity Test, Freshwater and Marine. EPA 712-C-96-118, United States Environmental Protection Agency, Washington, DC, USA.

Gavrieli, Y., Y. Sherman and S.A. Ben-Sasson 1992. Identification of programmed cell death in situ via specific labeling of nuclear DNA fragmentation. The Journal of Cell Biology 119(3): 493-501. http://doi.org/doi: 10.1083/jcb.119.3.493.

Ghosh, S.K., P. Chakaravarthy, S.R. Panch, P. Krishnappa, S. Tiwari, V.P. Ojha and A.P. Dash 2011. Comparative efficacy of two poeciliid fish in indoor cement tanks against chikungunya vector Aedes aegypti in villages in Karnataka, India. BMC Public Health 11(1): 599-606. http://doi.org/10.1186/1471-2458-11-599.

Heo, G. and G. Shin 2009. Acute and subacute toxicity of trichlorfon in guppies (Poecilia reticulata). Korean Journal of Veterinary Research 49(3): 253-256.

Haldsrud, R. and A. Krokje 2009. Induction of DNA double-strand breaks in the H4IIE cell line exposed to environmentally relevant concentrations of copper, cadmium, and zinc, singly and in combinations. Journal of Toxicology and Environmental Health, Part A 72(3-4): 155-163.

Humphries, M.S. 2013. Chemosphere DDT residue contamination in sediments from Lake Sibaya in northern KwaZulu-Natal, South Africa: Implications for conservation in a world heritage site. Chemosphere 93(8): 1494-1499.

http://doi.org/10.1016/j.Chemosphere.2013.07.0 47.

Kumar, R. and J.S. Hwang 2006. Larvicidal efficiency of aquatic predators: A perspective for mosquito biocontrol. Zoological Studies 45(4): 447-466.

Kusumawathie, P.H.D., A.R. Wickremasinghe, N.D. Karunaweera and M.J.S. Wijeyaratne 2006. Larvivorous potential of fish species found in 


\section{G.K.A.W. Fernando et al.}

river bed pools below the major dams in Sri Lanka. Vector Borne Diseases 43(1): 79-82. http://doi.org/http://dx.doi.org/10.1093/jmedent/ 43.1.79.

Kusumawathie, P.H.D., A.R. Wickremasinghe, N.D. Karunaweera and M.J.S. Wijeyaratne 2008. Costs and effectiveness of application of Poecilia reticulata (guppy) and temephos in anopheline mosquito control in river basins below the major dams of Sri Lanka. Tropical Medicine and Hygiene 102: 705-711.

http://doi.org/10.1016/j.trstmh.2008.03.013.

Kousar, S. and M. Javed 2015. Studies on induction of nuclear abnormalities in peripheral blood erythrocytes of fish exposed to copper. Turkish Journal of Fisheries and Aquatic Sciences 15(4): 879-886. doi: 10.4194/1303.

Lajmanovich, R., E. Lorenzatti, M.I. Maitre, S. Enrique and P. Peltzer 2003. Comparative acute toxicity of the commercial herbicides glyphosate to neotropical tadpoles Scinax nasicus (Anura: Hylidae). Fresenius Environmental Bulletin 12(4): 364-367. http://doi.org/10.1007/s00128-003-0029-x.

Li, P., X.B. Feng, G.L. Qiu, L.H. Shang and Z.G. Li 2009. Mercury pollution in Asia: A review of the contaminated sites. Journal of Hazardous Materials 168(2-3): 591-601.

http://doi.org/10.1016/j.jhazmat.2009.03.031.

Malins, D.C. and S.J. Gunselman 1994. Fouriertransform infrared spectroscopy and gas chromatography-mass spectrometry reveal a remarkable degree of structural damage in the DNA of wild fish exposed to toxic chemicals. Proceedings of the National Academy of Sciences (PNAS) 91(26): 13038-13041.

Mann, R.M. and J.R. Bidwell 1999. The toxicity of glyphosate and several glyphosate formulations to four species of southwestern Australian frogs. Archives of Environmental Contamination and Toxicology 36(2): 193-199. http://doi.org/10.1007/s002449900460.

Matthews, G. 2011. Integrated Vector Management: Controlling Vectors of Malaria and Other Insect Vector Borne Diseases. Wiley-Blackwell, Oxford, UK. 248 p.

Meyers, T.R. (ed.) 2000. Fish Pathology Section Laboratory Manual. Special Publication No. 12, $2^{\text {nd }}$ Edition. Alaska Department of Fish and Game, Commercial Fisheries Division, Juneau,
Alaska.

Nagaraju, B., P. Sudhakar, A. Anitha, G. Haribabu and V.V. Rathnamma 2011. Toxicity evaluation and behavioral studies of fresh water fish Labeo rohita exposed to rimon. International Journal of Research in Pharmaceutical and Biomedical Science 2(2): 722-727.

Nagaraju, B. and V.V. Rathnamma 2014. Determination of median lethal concentrations $\left(\mathrm{LC}_{50}\right)$ of freshwater fish Labeo rohita (Hamilton) for carbosulfan and its behavioral impacts. Journal of Stress Physiology and Biochemistry 10(3): 218-231.

Nehls, S. and H. Segner 2001. Detection of DNA damage in two cell lines from rainbow trout, RTG-W1, using the comet assay. Environmental Toxicology 16: 321-329. doi: 10.1002/tox.1039.

Negoescu, A., C. Guillermet, P. Lorimier, E. Brambilla abd F. Labat-Moleur 1998. Importance of DNA fragmentation in apoptosis with regard to TUNEL specificity. Biomedicine and Pharmacotherapy 52(6): 252-258.

http://doi.org/doi:10.1016/S0753-

3322(98)80010-3.

Nwani, C.D., W.S. Lakra, N.S. Nagpure, R. Kumar, B. Kushwaha and S.K. Srivastava 2010. Mutagenic and genotoxic effects of carbosulfan in freshwater fish Channa punctatus (Bloch) using micronucleus assay and alkaline single-cell gel electrophoresis. Food and Chemical Toxicology 48(1): 202-208.

http://doi.org/10.1016/j.fct.2009.09.041.

Qu, K., C.P.L.H. Chen, B. Halliwell, P.K. Moore and P.T. Wong 2006. Hydrogen sulfide is a mediator of cerebral ischemic damage. Stroke 37(3): 889-893.

http://doi.org/10.1161/01.STR.0000204184.349 46.41.

Ribeiro, C.A.D.O., A. Katsumiti, P. França, J. Maschio, E. Zandoná, M.M. Cestari, T. Vicari, H.Roche, H.C.S.D. Assis and F. Filipak Neto 2013. Biomarkers responses in fish (Atherinella brasiliensis) of paranaguá bay, southern Brazil, for assessment of pollutant effects. Brazilian Journal of Oceanography 61(1): 1-11. http://dx.doi.org/10.1590/S167987592013000100001.

Simoniello, M.F., F. Gigena, G. Poletta, A. Loteste, E. Kleinsorge, M. Campana, J. Scagnetti and M.J. Parma 2009. Alkaline comet assay for 
G.K.A.W. Fernando et al.

genotoxic effect detection in neotropical fish Prochilodus lineatus (Pisces, Curimatidae). Bulletin of Environmental Contamination and Toxicology 83(2): 155-158. https://doi.org/10.1007/s00128-009-9771-z

Wan, M.T., R.G.Watts and D.J. Moul 1989. Effects of different dilution water types on the acute toxicity to juvenile Pacific salmonids and rainbow trout of glyphosate and its formulated products. Bulletin of Environmental Contamination and Toxicology 43(3): 378-385. http://doi.org/10.1007/BF01701872.

Wickramasinghe, M.B. and H.H. Costa 1986. Mosquito control with larvivorous fish. Parasitology Today 2(8): 228-230.

Willems, K.J., C.E. Webb and R.C. Russell 2005. A comparison of mosquito predation by the fish Pseudomugil signifier Kner and Gambusia holbrooki (Girard) in laboratory trials. Journal of Vector Ecology, Journal of the Society for Vector Ecology 30(1):, 87-90.
Yarsan, E. and M. Yipel 2013. The important terms of marine pollution "biomarkers and biomonitoring, bioaccumulation, bioconcentration, biomagnification." Journal of Molecular Biomarkers and Diagnnosis S1: 003. doi:10.4172/2155-9929.S1-003.

Yi, M.Q., H.X. Liu, X.Y. Shi, P. Liang and X.W. Gao 2006. Inhibitory effects of four carbamate insecticides on acetylcholinesterase of male and female Carassius auratus in vitro. Comparative Biochemistry and Physiology-C Toxicology and Pharmacology 143(1): 113-116. http://doi.org/10.1016/j.cbpc.2005.12.008.

Zhu, T., K.K. Au-Yeung, Y.L. Siow and G. Wang, 2002. Cyclosporine A protects against apoptosis in ischaemic/reperfused rat kidneys. Clinical and Experimental Pharmacology and Physiology 29(9): 852-854. http://doi.org/10.1046/j.14401681.2002.03736.x. 